\title{
Arthropod-Plant Interactions celebrates its first impact factor
}

\author{
Heikki Hokkanen
}

Received: 2 August 2010/Accepted: 3 August 2010/Published online: 27 August 2010

(C) Springer Science+Business Media B.V. 2010

The 2009 Thomson ISI Impact Factors have recently been released, and we are delighted to announce that our very first Impact Factor rating is 1.714, ranking Arthropod-Plant Interactions on place 13 out of the 74 journals accepted for rating in the area of entomology. Among the ecologically oriented entomology journals with emphasis on original research articles, APIS already stands on the top of the list.

With this high first time Impact Factor the scientific community has convincingly demonstrated that there has been a demand for a journal dedicated to the ecological, biological, and evolutionary aspects of the interactions between insects and other arthropods with plants. The coverage of APIS includes all aspects of such interactions including chemical, biochemical, genetic, and molecular analysis, as well reporting on multitrophic studies, ecophysiology, and mutualism. On behalf of the whole editorial team of APIS I wish to thank all of you who already have contributed scientifically exciting manuscripts to our journal-and importantly, have not forgotten to cite the articles that we have published! Our strong and dedicated, internationally respected editorial board looks forward to continuing to serve you by providing the latest scientific discoveries on arthropod-plant interactions, and by speedy publishing of your important research results in this area.

After the latest Impact Factor ratings became available, APIS already has experienced a surge in the rate of manuscript submissions: in June-July of 2010 we have received four times as many manuscripts as in 2008, and twice as many as in 2009! This will inevitably result in an even increased Impact Factor rating for APIS in the future, but unfortunately also in an increased competition for printing space. The editorial team is inspired by these developments, and invites you to celebrate the success of APIS by enjoying free access to the top cited articles (please consult the journal website). We thank you all for your interest in APIS, and count on your continued support to the journal! 